\title{
PENERAPAN KEMAMPUAN PRESENTASI UNTUK MENINGKATKAN SPEAKING SKILLS MAHASISWA JURUSAN TEKNIK MESIN
}

\author{
Umi Anis $\mathbf{R}^{1}$, Atiqah Nurul Asri ${ }^{2}$, Abdul Muqit ${ }^{3}$ \\ 1,2,3 Jurusan Teknik Mesin, Politeknik Negeri Malang \\ umi.anis@polinema.ac.id ${ }^{1}$, atiqanu@polinema.ac.id ${ }^{2}$, muqit_abd@polinema.ac.id ${ }^{3}$
}

(Artikel diterima: Mei 2020, diterima untuk terbit: Juni 2020)

\begin{abstract}
Abstrak -Penelitian ini dilatarbelakangi dengan rendahnya kemampuan berbicara mahasiswa sedangkan kemampuan tersebut merupakan kemampuan yang penting dikuasai karena dapat menunjang pemahaman mata kuliah yang berhubungan dengan otomotif yang dipakai nanti pada saat presentasi laporan akhir/skripsi yang ditulis dan di ajukan menggunakan bahasa Inggri Penelitian ini dilakukan dengan tujuan untuk mendapatkan seberapa efektifnya presentasi ini untuk meningkatkan kemampuan speaking skill mahasiswa Metode penelitian ini termasuk jenis penelitian kualitatif yang menggunakan model pengembangan Kemmis dan Taggart yang meliputi; 1) planning, 2) implementing, 3) observing, dan 4) reflecting, dengan preleminary study sebagai pembukaannya. Populasi penelitian ini terdiri dari kelas 4A terdiri 23 orang dan 4B sebanyak 24 mahasiswa. Materi pelajaran yang diberikan adalah yang berbasis konteks karena hal ini yang dibahas sehari-hari. Hasil yang diperoleh pada kuesioner yang diikuti oleh mahasiswa kelas 4A dan 4B menunjukkan bahwa mereka tidak keberatan bahkan merasa lebih nyaman dengan presentasi kelompok dan mereka merasa lebih bisa berbicara bila dibandingkan dengan kelas kuliah atau lecturing. Dan dari data penelitian mahasiswa menunjukkan peningkatan pada kemahiran berbicara dari kelas 4A dari 55,44\% meningkat $63,01 \%$ dan dari kelas 4B dari 53,14 \% menadi $62,72 \%$
\end{abstract}

Kata kunci: berbicara, meningkatkan, presentasi.

\section{PENDAHULUAN}

Pada proses belajar mengajar ada beberapa faktor yang harus diperhatikan yang bisa menentukan kualitas pendidikan antara lain: 1. Pengajar, 2. Murid, 3.Kurikulum. Pengajar mewakili kemampuan atau kecakapan terhadap materi atau bahan ajar, metode, teknik dan sikap guru sendiri.Murid membawa motivasi intrinsik maupun ekstrinsik, dan sikap sedangkan kurikulum mengisi hal-hal yang berhubungan dengan perencanaan, silabus, media dan pendekatan dan asesment. Salah satu contoh yang penting disini adalah pengajar dan strategi karena strategi sangat erat hubungannya dengan pengajar.

Di jurusan Teknik Mesin Politeknik Negeri Malang khususnya program studi Ototronik D-IV bahasa Inggris diberikan pada semester kedua dan seterusnya.Selama ini strategi yang di pakai guru hanya ditentukan oleh reading compehension pada bidang studi atau pada content-subject matter dengan harapan mahasiswa bisa memahami dan mengerti buku yang dibahas.Padahal di akhir semester kemampuan mahsiswa kurang berkembang, Sebaliknya speaking sangat penting dan harusnya mahasiswa atau anak didik mendapatkannya sejak masih dini. Dengan mengajarkan kemampuan berbicara tujuan utama belajar bahasa Inggris akan tercapai. Salah satu tujuan diberikannya bahasa mereka yang berhubungan dengan bidang studi, mendiskusikan topik selain memahami buku yang harus mereka baca. (Buku Pedoman Politeknik, Jurusan Teknik Mesin)

Di program studi ototronik yang mayoritas mahasiswanya berasal dari sekolah menengah kejuruan, bahasa Inggris mereka kurang sekali terutama kecakapan berbicaranya salah satu penyebabnya mungkin dari pengajar sangat sulit memahami bahasa Inggris mahasiswa serta mengajar menggunakan strategi yang konvensional dan tidak mencoba dengan berbagai teaching strategi. Dari pengamatan awal kemampuan berbicara mahasiswa program stdi Ototronik dirasakan masih kurang memadai. Salah satu indikasinya adalah mahasiswa kurang kondusif dalam pelaksanaan kegiatan belajar mengajar didalam kelas.Mereka tidak memberikan respon yang memuaskan ketika melaksanaan tugas baik individu maupun kelompok. Sementara itu mata kuliah bahasa Inggris di semester II ini memerlukan kegiatan yang aktif dalam berkomunikasi yang aktif baik secara lisanl maupun tulisan. Suasana ini harus segera dibenahi agar kesalahan yang dilakukan oleh mahasiswa tidak terus berlanjut.Diantara masalah yang sering timbul adalah:

Kuliah yang sulit disekolah telah memberi dampak yang besar dalam motivasi mahasiswa belajar bahasa Inggris, karena hal tersebut dianggap sangat rumit untuk mempelajarinya. Mahasiswa menjadi pasif dan tidak termotivasi di kelas. Untuk mengatasi hal tersebut pengajar harus mencari strategi yang cocok agar atmosfer kelas bisa diterima semua kalangan.

Hasil tes pada awal studi menunjukkan bahwa mahasiswa masih mempunyai kesulitan untuk berkomunikasi secara lisan meski mereka sudah belajar beberapa tahun. Mereka jarang sekali menggunakan bahasa Inggris meskipun dalam ekpressi yang sangat sederhana. Disamping itu jika ada pertanyaan essai mereka menjawab dengan bahasa Indonesia. Masalah ini disebabkan beberapa faktor antara lain pengajar sering tidak memberi kesempatan untuk praktek speaking skill-nya, juga dengan strategi yang monoton mahasiswa jadi tidak meningkat komunikasinya. Faktor yang terakhir adalah rasa takut salah.

Rasa kurang percaya diri ini menyebabkan rasa kurang aman untuk menggunakan bahasa Inggris. Hal ini karena ada faktor psikologis yang harus dihilangkan dengan berkelompok dengan teman sebaya dalam belajar. Dengan memperkenalkan strategi baru, dan peserta didik perlu diberi reward untuk meningkatkan rasa percaya diri. 


\section{TINJAUAN PUSTAKA}

\section{A. Konsep Berbicara}

Speaking merupakan proses belajar yang aktif. Pertama, ketika ide didapat kemudian membentuknya dalam pesan dan mendeskripsikannya ke orang lain melalui suara dan tubuh. Pertama dengan mempelajari bagaimana membentuk percakapan yang efektif kita akan bisa menjadi pendengar yang lebih baik pada pembicaraan orang lain dan ini akan menuntun kitakearah speaking yang lebih baik.

Kedua dengan menguasai speaking dapat membantu mengusai skill yang penting ketika belajar di pergiruan tinggi. Grice and Skinner (2007:3) mengataka bahwa ;

"To succed in college students should be able to write andspeak with clarity and to read and listen with comprehension",

Dari keempat skill (mendengarkan, berbicara, membaca dan menulis) speaking rampaknya merupakan hal yang paling penting. Orang yang tahu bahasa dan dianggap "speaker" suatu bahasa seolah-olah termasuk mengetahui semua hal yang berbau bahasa tersebut.

Menurut Carnegie Foundation agar sukses sewaktu berkuliah seseorang seharusnya mempunyai kemampuan menulis dan berbicara secara jelas dan membaca dan mendengarkan dengan pemahaman. Juga dengan berbicara ( speaking yang benar seseorang akan lebih tampak berpenalaman

Berbicara adalah suatu proses yang aktif, setelah ide atau gagasan didapat kemudian mengolahnya menjadi pesan dan menyampaikan kepada orang lain melalui suara dan gerak tubuh. Proses berbicara merupakan tes yang sangat penting dalam mempromosikan pikiran kita. Dengan belajar bagaimana membangun percakapan yang effektif, kita akan menjadi pendengar yang baik dari pembicaraan orang lain, laporan dan kuliah sehingga nantinya akan meningkatkan proses pembelajaran,

Keuntungan ketiga berbicara akan meningkatkan kepercayaan diri. Meskipun hanya sebatas kecil saja yang kita berikan waktu presentasi maupun pembicaraan, kemampuan untuk berdiri di depan orang banyak merupakan suatu yang harus diperhitungkan. Untuk mempunyai keberanian yang besar perlu dikesampingkan hal-hal berikut:

\section{- Inhibitian}

Tidak seperti kegiata membaca, mendengarkan maupun menulis kegiatan berbicara memerlukan pendengar.Pembelajar sutu bahasa di kelas kuatir kalau membuat kesalahan, takut dikritik atau kehilangan muka atau behka hanya malu untuk mendapat perhatian.

\section{- Nothing to say}

Jika tidak karena inhibitant mereka mengeluh bahwa mereka idak ahu apa yang harus dikatakan. Tidak ada motivasi sama sekali untuk mengekspresikan diri dan bersalah karena harus berbicara.

\section{- Low participation}

Hanya beberapa orang saja yang mau berbicara kalau diberi kesempatan dan dengan kelompok yang agak besar berarti sedikit sekali orang yang mencoba mendominasi dan lainnya sama sekali tidak berbicara.
- Mother-tongue use

Dikelas yang bisanya banyak pembelajar berinteraksi dengan bahasa induk yang sama akan cenderung mengunakanya karena dirasa lebih mudah dan lebih manusiawi berbicata satu sama lain daripada menggunakan bahasa asing. Jika di kelompok kecil mereka bisanya agak kesulitan terutama yang tidak termotivasi.

\section{Solusi Berbacara}

Ur ( 1996:121) memberi beberapa hal cara mengatasi masalah yang ada hubungannya dengan speaking antara lain:

1. Menggunakan kerja kelompok

Hal ini bisa meningkatkan jumlah pembicaraan dalam waktu yang singkat dan inhibitant pembicara yang segan berbicara di depan kelas. Memang betul bahwa tidak setiap pengajar akan mendeteksi kesalahan-kesalahan tapi paling tidak yang mencolok pasti akan diketahui.

2. Kegiatan selalu dimulai dengan bahasa yang mudah

Secara umum level bahasa yang digunakan dalam diskusi seharusnya lebih rendah daripada di intensive klas supaya pembelajar mudah untuk memahami dan menghafal serta memproduksikannya dan mereka bisa berbicara dengan fasih tanpa keraguan.

3. Pilihlah topik yang menarik

Secara umum topik yang lebih jelas akan memotivasi seluruh peserta didik di kelas. Topik yang menarik adalah yang betul-betul di kuasai dan mudah dipahami oleh mahasiswa.

4. Berikan instruksi yang jelas pada saat diskusi

Jika tugas kelompok ini sudah dimengerti tinggal instruksi pada saat memulai diskusi. Contoh : pembelajar harus tahu bahwa semua orang di kelompok berkontribusi yang sama dalam diskusi, pilih ketua kelompok dalam diskusi untuk mengatur percakapan.

5. Tetap speakingpada bahasa sasaran

Pilih salah satu kelompok sebagai monitor yang tugasnya memonitor yang berdiskusi tetap pada target bahasa supaya mereka sadar bahwa ada yang mengawasi. Dan kalau semua dikerjakan dengan baik tinggal pengajar mengingatkan, modelling dan mengawasi.

\section{B. Presentasi}

Presentasi merupakan jenis ketrampilan berbicara yang menuntut pembicaranya memiliki kemampuan lebih dari sekedar berbicara, individu atau di depan massa yang sifatnya searah atau pidato. Ada empat aspek yang penting (menurut Comfort, 1995: 14), yaitu : 1) opening; yang terdiri dari salam pembuka, tittle, tujuan; 2) isi/body terdiri dari topik utama pembicaraan; 3) tanya jawab yang berisi beberapa pertanyaan ataupun pernyataan sebagai sanggahan atas apa yang dikemukakan oleh pemateri dan jawaban atau pembenaran atas pertanyaan tersebut; 4) closing (penutup), terdiri dari ringkasan semua pembicaraan dan ucapan terima kasih.

Berdasarkan pengalaman bentuk presentasi yang terkini adalah sekelompok orang duduk biasanya dalam setengah lingkaran di depan audiensi. Kemudian audiensi duduk di sekeliling yang sedang presentasi. Yang harus 
diperhatikan dalam presentasi menurut (Grice \& Skinner, 2007) adalah: 1) brain storming - topik yang akan dibahas; 2) membagi tugas; 3) membuat outline isi pembicaraan; 4) diskusikan seluruh topik yang akan dibahas; 5) rencanakan bagian opening, body, closing; 6) persiapkan dan latihan bagian isi pembicara.

\section{Konsep Pembelajaran Berbasis Vokasi}

Pada pembelajaran berbasis vokasi, bahasa diajarkan melalui content sebagai sarana untuk pemahaman dan seluruh unit dipelajari melalui contentnya. Dalam pembelajaran berbasis content, belajar bahasa dan informasi melalui materi yang berarti dan kontekstual, integrasi antara pencapaian akademis dan belajar bahasa adalah betul-betul yang pokok. Untuk mengetahui seberapa penting content based instruction diimplementasikan ada tiga hal yang harus diperhatikan, yaitu; berbasis centent, berpusat pada pembelajaran dan berfokus pada tugas. Yang pertama menurut Crandall \& Kaufman (2002) dalam content based harus berpusat pada content. Pembelajaran harus berinteraksi dengan topik yang dibahas, harus fokus pada masalah yang sedang dipelajari bukan bahasanya, yang kedua adalah pembelajaran dirancang untuk memenuhi sekelompok orang dan yang ketiga adalah berpusat pada tugas yaitu belajar sambil melakukannya.

Dalam belajar sesuatu pasti ada tujuannya dan pada pembelajaran berbasis content pembelajaran akan bisa mengekspresikan kepahaman tentang konsep, ide-ide topik yang tertulis dan mempresentasikan dalam bahasa Inggris bahkan juga mendemonstrasikannya.

Ciri khas pendidikan vokasi terletak pada praktik, sehingga diperlukanpembelajaran yang menghubungkan dengan pengalaman kehidupan yang nyata. Pada dasarnya semua pedekatan pembelajaran yang menghubungkan dengan pengalaman nyata merupakan pembelajaran berbasis konteks.

\section{Metode Penelitian}

\section{Rancangan Penelitian}

Penelitian ini dilaksanakan selama satu semester dimulai bulan 18 September 2018. Tempat penelitian adalah Jurusan Otomotif Elektronik, Teknik Mesin Politeknik Negeri Malang. Jadwal kegiatan penelitian sebagai berikut: tangal 18 September pelaksanaan pre-test, seminggu kemudian prencanaan metode dan review diskusi kelompok. Dua minggu setelah itu dijelaskan tentang metode presentasi sekaligus latihannya. Tanggal 30 Oktober mulai pelaksanaan presentasi sampai selesai. Tanggal 11Desember diadakan post-test dengan collaborative teacher kemdian pengambilan kuesioner dan analisa dilanjut dengan refleksi dan penyusunan laporan.

Penelitian ini gagasannya adalah classroom action research (penelitian tindakan kelas) yang mencoba sebuah pembelajaran beride pada konteks (Kosyi , 2007)Pembelajaran yang mengacu pada konteks ini sesuai dengan kurikulum D-IV, yaitu mengenai bahasa Inggris yang mengacu pada pecakapan berbicara khususnya untuk kehidupan yang berhubungan dengan bidang studi mereka. Proses belajar yang diterapkan adalah presentasi. Sebelum presentasi dalam pelaksanaan action research selalu didahului preluminary study atau pemberian pre-test untuk mengidentifikasi masalah yang timbul di kelas. Sehingga peneliti melalui classroom action research bisa merefleksi, mengobservasi serta mengeksplorasi melalui pengajarannya, mencoba ide-ide atau metode baru kemudian menilai keefektifannya. Bersama collabortive teacher, pengajar mengadakan pre-test dan kemudian post-test setelah melalui tahap-tahap seperti pada action research.

\section{E. Model Pengembangan}

Desain penelitian yang ditetapkan disini adalah Penelitian Tindakan Kelas (PTK) atau Classroom Action Research (CAR). Kasbolah dan Sukaryana (2001:9) menyatakan bahwa Classroom Action Research adalah salah satu usaha yang dibuat atau diciptakan oleh pengajar atau praktisi dalam berbagai aktivitas yang dilaksanakan supaya meningkatkan kondisi yang tidak memuaskan atau meningkatkan qualitas sistem pembelajaran. Lebih lanjut, Latief (2003:99) menyatakan bahwa CAR berusaha menemukan strategi mengajar yang cocok dengan mahasiswa. CAR yang dibuat meliputi pengajar dan kolaborasi dengan pengajar yang lain yang akan mengobservasi kegiatan kelas. Desain CAR yang diadaptasi dari Kemmis dan Mc Taggart (1998) meliputi: 1) planning the action (perencanaan), 2) implementing of action/ (pelaksanaan), 3) observing the action ( pengumpulan data), 4) reflectin (analisa data) seperti terlihat padadiagram dibawah ini.

Sebelum langkah pertama dimulai biasanya di lakukan preliminary studi yang dirumuskan dengan skala kemampuan berbicara seperti yangditunjukkan oleh Djiwandono(2007:56) dalam tabel berikut

\section{F. Perencanaan (planning the action)}

Tahapan dalam action research salah satunya yaitu perencanaan. Dalam tahap ini dibuat langkah-langkah implementasi metode pengajaran dengan presentasi rencana awal adalah merancang jadwal dan materi presentasi beserta kelompoknya. Kedua menentukan standar penguasaan kemampuan berbicara yang terdiri dari isi, susunan, bahasa dan lafal. Ketiga adalah menyiapkan mahasiswa dengan latihan dan simulasi sebelum presentasi. Keempat dengan collaborative teacher menganalisa data untuk post-testnya.

\section{G. Pelaksanaan (implementing the action)}

Tahap selanjutnya adalah presentasi dilakukan selama enam minggu untuk masing-masing pertemuan, yang berdurasi dua jam mata kuliah. Untuk setiap pertemuan peneliti mencatat kemajuannya.

\section{H. Observasi}

Tahap observasi dilakukan dengan pengamatan pada masing-masing individu. Masing-masing mahasiswa sudah bisa menjalankan aturan sesuai dengan waktu pelatihan. Pengamatan ini dilakukan berdasar pre-test dan post-test yang diadakan di akhir siklus. Selain juga pada pengamatan secara kelompok. Disini juga sekaligus ditetapkan kriteria sukses dari sample dan mengimplementasikan speaking skill sudah terpenuhi apa belum.

\section{Refleksi}

Fokus dari siklus ini adalah evaluasi atau penilaian tentang kriteria sukses dari mahasiswa. Dengan evaluasi ini 
pengajar membuat rujukan tantang keefektifan strategi yang dipakai. Proses dari reflecting ini meliputi observasi kelas, dan score mahasiswa.

Setelah langkah terakhirin, pengajar memutuskan apakah harus berheti atau kembali ke awal untuk melanjutkan siklus berikutnya. Jikakriteria sukses belum terpenuhi pengajar harus mengulang dari langkah awal dansebaliknya kalau kriteria sukses terpenuhi berarti bisa berhenti.

Tabel Skala Tingkat Kemampuan Berbicara

\begin{tabular}{|c|l|l|l|l|}
\hline NILAI & \multicolumn{1}{|c|}{ ISI } & SUSUNAN & \multicolumn{1}{c|}{ BAHASA } & LAFAL \\
\hline 4 & $\begin{array}{l}\text { Isi amat } \\
\text { sesuai topik } \\
\text { Kaya } \\
\text { rincian isi }\end{array}$ & $\begin{array}{l}\text { Amat } \\
\text { sistematis }\end{array}$ & $\begin{array}{l}\text { Tata bahasa } \\
\text { amat baik } \\
\text { Kosakata amat } \\
\text { tepat }\end{array}$ & $\begin{array}{l}\text { Lafal } \\
\text { amat baik } \\
\text { dan amat } \\
\text { jelas }\end{array}$ \\
\hline 3 & $\begin{array}{l}\text { Isi sesuai } \\
\text { topik } \\
\text { Rincian isi } \\
\text { cukup }\end{array}$ & Sistematis & $\begin{array}{l}\text { Tata bahasa } \\
\text { baik } \\
\text { Kosakata tepat }\end{array}$ & $\begin{array}{l}\text { Lafal } \\
\text { baik dan } \\
\text { jelas }\end{array}$ \\
\hline 2 & $\begin{array}{l}\text { Isi kurang } \\
\text { sesuai } \\
\text { Rincian } \\
\text { kurang }\end{array}$ & $\begin{array}{l}\text { Kurang } \\
\text { sistematis }\end{array}$ & $\begin{array}{l}\text { Tata bahasa } \\
\text { kurang baik } \\
\text { Kosakata } \\
\text { kurang tepat }\end{array}$ & $\begin{array}{l}\text { Lafal } \\
\text { kurang } \\
\text { baik dan } \\
\text { kurang } \\
\text { jelas }\end{array}$ \\
\hline \multirow{2}{*}{1} & $\begin{array}{l}\text { Isi tidak } \\
\text { sesuai } \\
\text { Tidak ada } \\
\text { rincian }\end{array}$ & $\begin{array}{l}\text { Tidak } \\
\text { sistematis }\end{array}$ & $\begin{array}{l}\text { Tata bahasa } \\
\text { tidak baik } \\
\text { Kosakata tidak } \\
\text { tepat }\end{array}$ & $\begin{array}{l}\text { Lafal } \\
\text { tidak baik } \\
\text { dan tidak } \\
\text { jelas }\end{array}$ \\
\hline
\end{tabular}

\section{J. Subyek Penelitian}

Subyek penelitian ini adalah kelas 4A dan 4B dengan jumlah mahasiswa 23 dari kelas $4 \mathrm{~A}$ dan $4 \mathrm{~B}$ berjumlah 24. Untuk membuat kelompok, mahasiswa bersepakat 5 kelompok dengan 4 orang mahasiswa dan satu kelompok 3 orang dari kelas 4A dan 6 kelompok dari kelas 4B dengan 4 orang mahasiswa.

\section{K. Instrumen Penelitian}

Instrumen utama penelitian yang dijadikan indikator hasil pre-test dan hasil post-test yang diberikan oleh collaborative teacher.Tes yang digunakan adalah untuk meningkatkan kemampuan berbicara mahasiswa yang akan diujikan waktu pre-tes dan post-tes dalam bentuk presentasi. Pre test ini bertujuan untuk mengetahui seberapa besar penguasaan terhadap isi, susunan, bahasa dan lafal yang dimiliki oleh mahasiswa sebelum diberi latihan. Kemudian untuk mengetahui seberapa besarnya kenaikan content tersebut mahasiswa diberikan post-test secara individu pada akhir penerapan metode. Materi yang diberikan adalah materi dari buku panduan mereka yang belum terindikasi adanya keempat langkah planning, implementing, observing dan reflecting. Setiap presentasi memerlikan waktu $2 \times 45$ menit dan diharapkan semua selesai)

\section{Koleksi Data}

Pengajar dan teman sejawat sebagai pengajar kolaborativeakan mengadakan test sebagai salah sau cara untuk memperoleh nilai dari speaking skill untuk mengetahui strategi yang diterapkan meningkatkan performa atau qualitas mereka. Dengan menggunakan tabel 4.2 sebagai dasar dalam penghitungan nilai speaking mereka..
Hasil tes kemudian diolah dengan formula:

$$
\text { Skor }=\frac{\text { Jumlah Skor }}{\text { Jumlah Skor Maksimal }} \quad x \quad 100 \%
$$

\section{Analisis Data}

Pada penelitian kualitatif analisis data berlangsung mulai awal sampai berakhir kemudian di tuang dalam laporan. Data yang sudah dianalisis akan mengarah pada penemuan penelitian. Kalau mahasiswa mendapat penyampaian yang tinggi setelah perlakuan berarti strategi yang dijalankan efektif dan peneliti berhasil dalam mengaplikasikan. Tapi kalau tidak mencapai standard yang diinginkan atau dibawah nilai standar berarti strateginya belum efektif dan harus diulang dengan perencanaan dari awal.

\section{Pembahasan}

\section{A. Data Hasil Pengamatan}

Hasil kuesioner ini diberikan pada mahasiswa kelas 4A dan 4B jurusan Ototronik D-IV, karena mereka yang tahu pasti apakah metode pembelajaran ini cocok atau tidak nantinya.

Pertanyaan pada kuesioner meliputi: kesukaan dengan cara group discussion; pemahaman dengan group discussion; tingkat kesulitan group discussion; partisipasi dalam presentasi; pertanyaan dari mahasiswa lain; pertanyaan dosen; jawaban saya dipahami; penjelasan saya dalam mengemukakan pendapat; sering menjawab dalam presentasi; kesulitan yang dihadapi dalam berbicara; dan hasilnya sebagai berikut:

Untuk kelas 4A yang paling sulit ternyata "pengorganisir ide" sebanyak 41,7\%. Kemudian dilanjutkan dengan menyusun kalimat dengan tata bahasa yang tepat sebangak 33,3\% dan kemudian 16,7\% mahasiswa kosa katanya kurang pas untuk maksud tertentu dan yang terakhir pada pengucapan ada 2 orang mahasiswa. Untuk kelas 4B ternyata agak seragam yaitu $23,8 \%$ untuk kosa kata dan menyusun kalimat sedang yang terbanyak kesulitannya $33,3 \%$ pada pengorganisir ide dan ada 4 orang mahasiswa yang pengucapannya susah.

\section{B. Data Hasil Penelitian}

Berdasarkan hasil perhitungan pre-test yang dilakukan secara individu di dua kelas yang berbeda yaitu 4A dan 4B D-IV diperoleh data bahwa rata-rata mahasiswa dikelas 4A nilai speaking cukup sesuai dengan standart konvensi nilai yang diberlakukan di Politeknik Negeri Malang. Nilai rerata kelas $4 \mathrm{~A}$ pada saat pre-test $55,44 \%$ dan naik menjadi $63,01 \%$ pada saat post-test sementara nilai rerata mahasiswa kelas 4B program studi D4 memiliki penguasaan speaking lebih rendah yaitu $53,14 \%$ pada sat pre-test dan meningkat menjadi $62,72 \%$ pada saat menjalani post-test.

Dari hasil pre-test juga disimpulkan bahwa ada 6 mahasiswa dengan nilai "baik" bahkan 1 orang mahasiswa dengan nilai sangat baik. Sedangkan sisanya berada pada posisi kurang. Dari hasil test tersebut didapat kesimpulan bahwa mahasiswa kelas 4B D-IV yang masih memiliki 
kekurangan program kemahiran berbicara terutama pada aspek bahasa dan susunanya.

Dari kelas 4A program study D-IV nilai speaking mereka sangat kurang. Hanya ada 3 orang mahasiswa yang mendapat nilai "lebih dari baik" dan hanya 1 orang dengan predikat baik. Sedang sisanya berada pada level "kurang".

Sedangkan dari hasil post-test kelas 4A program study D-IV, 5 orang mahasiswa mendapat nilai sangat baik, dan 8 orang mahasiswa mendapat level lebih dari baik. Sementara 8 orang mahasiswa berada pada level baik sedangkan yang lebih dari cukup ada 2 orang mahasiswa dan sisanya termasuk kategori kurang.

Disisi lain pada kelas 4B program study D-IV mahasiswanya tergolong rendah. Hanya ada 4 orang mahasiswa dengan predikat lebih dari baik, yang baik hanya 3 orang, sedangkan yang lebih dari cukup 15 orang dan sisanya 2 pada level kurang.

Dibawah ini adalah tabel-tabel tentang nilai mahasiswa pemberian skor adalah dari hasil hasil pre-test, kemahiran berbicara, kemudian hasil post-test.

Dari hasil pengamatan pada observasi semua kelompok melakukan presentasi dengan baik, dimulai dengan membuka salam. Demikian juga waktu mereka menyebut nama, dan kelompok dengan judul presentasi juga dilakukan dengan baik. Namun waktu menyebut tujuan presentasi hanya kelompok Febrio, Husni, dan Rahman dari kelas 4A dan El Claudio dan Masyofi dari kelompok kelas 4B.. yang dilakukan dengan tepat.

Dari ke-enam kelompok kelas 4A program study D-IV, hanya Febrio, Rahman dan Husni yang betul-betul sempurna baik pada waktu mepresentasikan bagian body maupun pada closing disertai waktu tanya jawab berlangsung lancar.

Pada kelas 4B D-IV ada 3 kelompok yang bisa dikategorikan baik yaitu El Claudio, Yan dan Masyofi dalam mempresentasikan makalahnya. Pada saat membuka dan menutup presentasi dilakukan dengan baik, namun ketika masuk pada masalah isi presentasi agak keteteran, yang menyenangkan dari kedua kelas tersebut di atas adalah bahwa yang menjadi content pembicaraan berasal dari bidang study mereka.

\section{Pembahasan}

Untuk melakukan observasi dilakukan pengamatan pada kemahiran berbicara mahasiswa kelas 4A dan kelas 4B program study D-IV Teknik Mesin. Pengamatan dilakukan pada hari Senin saat mahasiswa melakukan presentasi dan saat mereka berdiskusi kelompok. Hasil pengamatan kemahiran berbicara menunjukkan bahwa secara umum proses berbicara belum maksimal terutama untuk kelas 4B. Hal ini bisa dilihat pada tahap pelaksanaan dan tahap refleksi. Tapi meski hasilnya belum maksimal terutama untuk kelas 4B rerata peningkatannya menunjukkan ke level yang bisa dikatakan baik yaitu 62,72\%. Sedangkan untuk kelas 4A program study D-IV reratanya sudah lebih baik di level 63,01 \% dengan kategori cukup. Ada beberapa mahasiswa yang menunjukkan nilai sangat tinggi pada nilai post-testnya seperti pada nilai 94 dan 88

Tahap preliminary-study pengajar tidak menggunakan metode dan strategi tertentu untuk mengajarkan proses berbicara (speaking skill) pada mahasiswa. Mereka langsung diminta presentasi. Banyak mahasiswa yang tidak memperhatikan mereka acuh tak acuh dan tidak siap presentasi, sesi tanya jawab tidak berlangsung menarik.

Pada sesi pertemuan pertama yang dibahas adalah konsep small group discussion tentang berapa orang dalam satu kelompok, pembagian tugas, pembagian waktu presentasi kemudian konsep presentasi. Ada tiga hal yang harus diperhatikan dengan adanya presentasi yaitu pembukaan bagian pokok dari presentasi atau body dan penutup dan ketiga faktor ini sangat dominan terutama adalah bagian pokok. Pada sesi pertemuan berikutnya membahas kemampuan berbicara dari isi, susunan, bahasa dan lafal. Dari segi isi ada amat sesuai, sesuai, kurang sesuai dan tidak sesuai.

Dari susunan bisa dilihat apakah pembicaraannya membawakan materi tersebut dengan sistematis atau tidak, sedangkan dari segi kebahasaan tata bahasa, dan kosakatanya tepat apa tidak. Sementara dari segi lafal baik atau amat jelas sampai tidak baik dan tidak jelas.

Simulasi presentasi yang dilakukan pada sesi kelima bulan Juni. menunjukkan adanya peningkatan baik dari isi, susunan, bahasa dan lafal. Bahkan pada jadwal sesi ke-enam mahasiswa berusaha presentasi dengan volume suara yang keras dan bahasa yang tertata rapi, juga susunan kalimatnya jadi jelas. Namun sayang untuk kelas 4B program study D-IV masih kurang terutama masalah isi kurang padat.

Berdasarkan hasil penelitian diperoleh hasil:

1) Mahasiswa belum mampu menyajikan materi secara lengkap

Kelengkapan materi bisa dilihat dari definisinya, fungsi, tujuan dan prosesnya dan lain sebagainya Kadang mahasiswa hanya menyebutkan tiga atau dua saja dan mahasiswa lain harusnya menutup kekuranga tersebut..

2) Mahasiswa belum mampu berbicara sistematis

Sistematis disini berarti secara runtut dari hal yang paling rendah tingkatannya atau mungkin dari yang paling mendasar misalnya dengan menyebutkan dulu perangkatnya baru masuk pada pokok permasahan.

3) Mahasiswa belum mampu menjawab pertanyaan dan sanggahan

Tahap terakhir adalah yang paling penting yaitu bagaimana menjawab pertanyaan dansanggahan. Ditahap ini mahasiswa banyak yang belum bisa melakukannya dengan baik

Pelaksanaan ini belum sepenuh nya berhasil karena kompensasi materi dari opening, body dan closing yang disertai tanya jawab tidak terlaksana dengan baik. Memang tidak semua berhasil dengan sempurna seperti contoh kelas 4A dan 4B D-IV karena terbatas waktu dan pelaksanaan.

\section{Simpulan Dan SARAN}

\section{A. Simpulan}

Penelitian yang dilakukan ini merupakan penelitian tindakan kelas (classroom action researh) yang mencoba suatu pengajaran dengan metode tertentu yang berbasis konteks dengan didahului dengan preliminary study kemudian diberi pre-test setelah melalui berbagai langkah di berikan post-test.

Penelitian ini diawali dengan mendata masalah yang mendasar ditemui pada kelas Ototronok yaitu kemahiran berbicara yang dirasakan oleh pengajar kelas tersebut sangat kurang. Hal ini menghambat kemampuan berkomunikasi dalam bahasa Inggris. Untuk itu sebagai uasaha untuk meningkatkan kemahiran berbicara mahasiswa dilakukan 
presentasi yang sebelumnya di dahului oleh latihan dalam small group discussion. Diskusi kelompok ini terdiri dari masing-masing empat orang mahasiswa yang masingmasing mendapat porsi yang akan dibahas dalam presentasi.

Dalam penelitian ini juga melalui siklus penelitian tindakan kelas yaitu tahap perencanaan, pelaksanaan,observasi dan refleksi.Sebetulnya masih perlu satu siklus lagi untuk mencapai target tetapi karena terbatasnya waktu mungkin perlu waktu yang lebih panjang.

Secara umum berdasarkan hasil pengamatan dan penelitian dapat disimpulkan bahwa kemahiran berbicara mahasiswa dapat ditingkatkan melalui latihan yaitu dengan diskusi kelompok. Mahasiswa meresa lebih nyaman dan lebih relaks waktu berbicara di depan kelas karena mereka sebelumnya sudah dilatih terlebih dahulu. Mereka juga merasa nyaman dan leluasa dikarenakan suasana kelas lebih santai dan mereka menganggap seolah-oleh saya tidak ditempat. Kemahiran berbicara mahasiswa meliputi aspek isi, bahasa, susunan dan lafal. Pada aspek isi sebelum diterapkannya latihan mahasiswa tidak menyiapkan materi dengan baik sehingga presentasi tampak kurang menguasai materi. Hal ini menyebabkan audiensi kurang memahami, selain itu suasana pembelajaran menjadi kurang kondusif. Tidak ada sesi tanya jawab.

Pada aspek bahasa sebelum latihan berbicara dengan suara yang tidak dengar, puluhan kata yang tidak jelas setelah latihan mahasiswa berbicara dengan suara jelas tidak keselo dan lafal yang nyaring, tepat, meski intonasi kurang tepat.

Pada aspek persentasi sebelum tidak diperhatikan padahal sangat penting penampilan, karena secara tidak langsung berpengaruh kertarikan audiensi terhadap materi. Setelah pelatihan ada kontak mata yang fokus dan komunikatif, dan gerak isyarat yang mendukung isi pembicaraan.

Selain latihan berdampak pada kemahiran berbicara metode berdampak pada proses pembelajaran. Metode yang aplikatif membuat mahasiswa tidak bosan mengikuti pembelajaran. Banyak hal baru didapat sewaktu presentasi dengan tanya jawab.

\section{B. Saran}

Peneliti sangat menyadari bahwa kemahiran berbicara sangat penting dilakukan, namun pelaksanaannya sangat sulit terutama yang bersifat pendiam. Motivasi pembelajaran tentu harus ditumbuhkan dengan konsep dan topik bahasan yang lebih dekat dengan dirinya, misalnya dengan topik keseharian yang digelutinya, yaitu dengan combustion, spark plug, machine operation, beat the breakdown dan machine design. Dengan cara seperti itu mahasiswa akan tampak sangat bersemangat. Selanjutnya diharapkan para pengajar lebih meningkatkan lagi konsep action research ini dimasa yang akan datang. Dengan strategi dan metode yang lain bisa didapatkan hasil yang lebih baik dan peningkatan lebih berhasil. Juga dilihat dari proses peningkatan yang di dapat mahasiswa masih kurang sedikit dari harapan mungkin dapat dilanjutkan nanti pada semester selanjutnya.

\section{DAfTar Pustaka}

[1] Brown, H.Douglas.2001. Teaching by Principle: An Interactive Approah to Language Pedagogy.Longman.

[2] Brown, H. Douglas. 2007. Prinsip Pembelajaran dan Pengajaran Bahasa. San Fransisco, Pearson Education inc

[3] Ur, Penny. 1996.A Course in Language Teaching: Practice and Theory. Cambridge: Cambridge University Press

[4] Comfort, J. 1995. Effective Presentation. Oxford University Press. Oxford

[5] Crandall, J \& Kaufman, D (eds) 2002. Content based instruction in higher education setting. Virginia. Tesul Inc.

[6] Djiwandono, M S.2007. Tes Bahasa: Pegangan bagi Pengajar Bahasa.

[7] Grice, G L and Skinner, John F.2007. Mastering Public Speaking. Boston: Pearson Education Inc

[8] Kemmis, S \& Mc Taggart, R. 1998. The Action Reseach Planner. Victoria, Deakin University Press

[9] Koshy, Valsa. 2007. Action Research for Improing Practice. London

[10] Latief, M Adnan, 2003. Penelitian Tindakan Kelas Pembelajaran Bahasa Inggris. Jurna Ilmu Pendidikan. Juli X No 2

[11] Politeknik Negeri Malang, (2016). Buku Pedoman Pendidikan Program Studi Ototronik Jurusan Teknik Mesin Politeknik Negeri Malang.

[12] Ur, Penny. 1996.A Course in Language Teaching: Practice and Theory. Cambridge: Cambridge University Press 